\title{
A Study of Translation Students' Self-Regulation and Metacognitive Awareness in Association with their Gender and Educational Level
}

\author{
Mona Hashempour \\ Imam Reza International University, Mashhad, Iran \\ Behzad Ghonsooly \\ Ferdowsi University of Mashhad, Iran \\ Afsaneh Ghanizadeh (Corresponding author) \\ Imam Reza International University, Mashhad, Iran
}

Received: 09-05-2015

doi:10.7575/aiac.ijclts.v.3n.3p.60
Accepted: 18-07- 2015

Published: $31-07-2015$

\begin{abstract}
The present study sought to investigate the probable link between Iranian English translation studies students' metacognitive awareness, self-regulation, and gender. Furthermore, the role of educational level of translation students in metacognitive awareness and self-regulation was explored. For the purpose of the study, a sample of 230 M.A and B.A senior English translation students comprised the participants of the research. They were asked to complete two questionnaires of Metacognitive Awareness Inventory (MAI) and Self-regulation Trait (SRT).The Metacognitive Awareness Inventory (MAI) was developed by Schraw and Dennison (1994) and consists of 52 statements. It measures two components of metacognition: metacognitive knowledge and metacognitive regulation. Metacognitive knowledge comprises three subscales: Declarative knowledge, Procedural knowledge, and Conditional knowledge. Metacognitive regulation consists of five subscales: Planning, Information management, Monitoring, Debugging, and Evaluation. The self-regulation trait (SRT) questionnaire was designed by O'Neil and Herl (1998). It was developed based on Zimmerman's self-regulation model. It consists of 32 Likert-scale questions. The scale seeks to measure metacognition and motivation dimensions. Each dimension comprises two sub-scales. Meta-cognition covers the constructs of planning and self-monitoring, and motivation contains effort and self-efficacy. Independent samples $t$-tests were run to investigate the role of gender and educational level in the level of translation students' metacognitive awareness and self-regulation. The results of $t$-test demonstrated that there are not any differences between male and female translation students regarding metacognitive awareness and self-regulation. It was also found that there is a negative significant impact of educational level on total metacognitive awareness, and some components of metacognitive awareness: declarative knowledge, conditional knowledge, and evaluation. In other words, MA students were shown to have higher levels of metacognitive awareness in comparison with their BA counterparts. Finally, no significant differences between educational level and self-regulation were obtained.
\end{abstract}

Keywords: Gender; Educational Level; Metacognitive Awareness, Self-regulation, Translation studies

\section{Introduction}

Translation has an important place in the development of different societies all over the world. The act of cross-cultural communication is somehow impossible without translation and translators; so, they play a significant role in human interactions. Robinson (1997) stated that "the study of translation and the training of professional translators is without question an integral part of the explosion of both intercultural relations and the transmission of scientific and technological knowledge" (p.2). Recently, some research in Translation Studies have focused on a rather new trend which is called "Translator Studies" (e.g. Chesterman, 2009; Dam \&Zethsen, 2008; Diriker, 2004; Fukari\& Wolf, 2007; Koskinen, 2008; as cited in Chesterman, 2009).The term "Translator Studies" refers to a research tendency in which the main focus has been shifted to translators rather than translation as a product or process. In this new trend, it can be useful to pay attention to different aspects, one of which can be translators' psychological characteristic.

In the current study, two learner-related psychological factors- metacognitive awareness and self-regulation- are studied. These variables were selected because each of these constructs have significant role in successful learning and in student's achievement (Bandura, 1997; Schraw, 1994; Zimmerman, 1989). In particular, the role of gender and educational level in each of these variables has been investigated in this study.

Metacognitive awareness and self-regulation are psychological factors that cause differences in the performance of students. Educational psychologists have given importance to the term metacognition for couple of decades, because metacognition is important in learning and is a strong predictor of academic success (Kruger \& Dunning, 1999). 
Metacognition is defined as "an individual's knowledge and control over one's own cognitions" (Schraw\& Dennison, 1994, p. 25). Human beings rich in metacognitive awareness are proficient at directing their progress towards targets, finding out their qualities and shortcomings, and adapting their learning strategies appropriately to obtain beneficial outcomes (Flavell, 1979). Research discoveries imply that metacognitive strategies distinguish successful learners from unsuccessful ones. The recent studies confirmed that learners who metacognitively aware perform better than unaware learners (Garner \& Alexander, 1989; Pressley \&Ghatala, 1990, as cited in Schraw\& Dennison, 1994). Mainly because metacognitive awareness helps learners to decide, organize and adjust their learning in a way that improves performance (Schraw, 1994).

Until recently, there has been very little empirical evidence about the ways students become master in their learning, a subject that regarded as self-regulated learning (Zimmerman \&Schunk, 1989). Self-regulation is best described as 'selfgenerated thoughts, feelings, and movements that are arranged and cyclically adapted to the fulfillment of personal goals' (Zimmerman 2000). In the context of education and learning, self-regulatory skills are commonly discovered relevant to students' success and willingness (Zimmerman \&Schunk, 2001). Self-regulated learners perform their assignments with certainty, constancy, and resourcefulness. They are aware of their capabilities and skills. In contrast with passive students, once self-regulated learners face troubles which can include inadequate learning situations, misleading trainers, or the insufficient source, they realize how to make it. For these students, acquisition is a systematic and manageable procedure. Self-regulated learning (SRL) is a pivotal field of research in college learning and teaching (Pintrich, 1995).

Although metacognitive awareness and self-regulation as psychological factors have recently gained attention in higher educational research, these constructs have rarely been investigated in the realm of translation studies.

Researchers have always claimed that translation has to do with translators' talents and consider translation as an art, not only a technique (Ghanavati, 2008). Studying the impact of different translation strategies on the process and product of translation is considered as one of the important aspects of translator studies, since it is very important for translation teachers and evaluators to consider different aspects of translators' mind in order to teach and evaluate more delicately. Therefore, it is necessary to focus on students mental, cognitive and communicative skills.

Metacognitive awareness and self-regulation are cognitive skills which can impact performance and are typically classified as factors liable for individual differences .In other words, these variables are different across individuals and tend to vary according to personal factors, such as, gender, personality, experience, educational background, and so on.

As far as the researchers of the present study looked for, there was no documented study on the metacognitive awareness and self-regulation of translator students with respect to their personal factors. So the main problem addressed in this study is assessing and analyzing metacognitive awareness and self-regulation as individual variables among translation students. In particular, it seeks to explore these two achievement-associated constructs in relation to two personal factors, i.e., gender and educational level. In other words, we aimed to examine whether these constructs vary between male and female translators and whether they develop as translators advance to higher educational level. To see the progression of these possible fluctuations, statistical analyses were run not only for each variable but also for the comprising subscales of each.

\section{Research on Metacognitive Awareness}

One of the difficulties in carrying out research into metacognition is the diversity of related concepts that can be found in the literature referring to the same phenomenon: metacognition, metacognitive knowledge, learner beliefs, and consciousness-raising or awareness-raising. It is important to highlight the fact that metacognition is a multidimensional phenomenon (Schraw, 1998). Flavell (1970) defined Metacognition as an individual's knowledge and control over one's own cognitions and also Schraw put it in this way "the ability to reflect upon, understand and control one's learning" (Schraw\& Dennison, 1994). Two categories were distinguished for metacognition, including knowledge of cognition and regulation of cognition (Flavell, 1979). He classified knowledge of cognition into three categories: person, task, and strategy knowledge. Person refers to general knowledge one has about human beings' cognitive capabilities. Task is the knowledge about the nature of the task and finally strategy indicates the knowledge about strategies that may be useful for different tasks and in different situations.

However, some other researchers such as Schraw (1994) have differently categorized components of metacognition. Accordingly, three types of knowledge are proposed: declarative knowledge or the knowledge about self and about strategies; procedural knowledge which is the knowledge about how to use strategies and conditional knowledge which relates to knowledge of when and why to use strategies. Regulation of cognition includes a set of sub-processes that regulate and facilitate the control of aspects of learning (Schraw\& Dennison, 1994). The skills of this component are planning, monitoring and evaluation (Schraw, 1998). Planning includes goal setting and choosing the appropriate strategies before involving in learning. Monitoring is consideration of learning, task performance and the use of strategy while engaging in an activity. Evaluation is an assessment of learning outcomes and strategies to examine whether the goals have been achieved (Schraw, 1998).

Developing metacognition is necessary for academic achievement. Research on the history of metacognition demonstrate that learning and metacognitive awareness were associated since the goal of metacognition is regulating and directing learning. Recent research indicates that metacognitively aware learners are more strategic and perform better than unaware learners (Garner \& Alexander, 1989). Most researchers agree to provide learners with the best environment to benefit from metacognitive training to improve their metacognition and academic performance. "The 
majority of investigations into classroom interventions which incorporate metacognition as a part of their programs consider the impact of metacognitive training on EFL learners' academic success" (Coutinho, 2007; Kassaian \& Ghadiri, 2011; Mohammadi Ghavam, Rastegar, \&Razmi, 2011; Negretti \& Kuteeva, 2011; Sheorey\& Mokhtari,2001; Vandergrift, 2005; Zhang \& Wu, 2009; as cited inHeidari \& Bahrami, 2012). One of the studies that investigate the relationship between metacognition and learning achievements is Coffey (2010) who found that good metacognitive awareness lead to success in writing. On the other hand, Young and Fry (2008) concluded that there are correlations between metacognition and college students' Grand Point Average (GPA).

\section{Research on Self-regulation}

Self-regulation is the control that ones have over their cognition, behavior, emotions and motivation through the use of personal strategies to achieve the goals they have established. In accordance with Bandura's social cognitive theory, self-regulation is the reciprocal interaction among personal, behavioral and environmental aspects (Zimmerman, 1998, 2000). Relying on this theory, Zimmerman states that when learners become metacognitively, motivationally and behaviorally active participants in their own learning procedure, we can define them as being self-regulated (Zimmerman, 1989, 1990).

Three aspects of self-regulation are as follows: (Zimmerman, 1989):

Self-Regulation of Behavior: Learners are in active authority over the resources that are obtainable to them which can include the right time, their study condition (e.g., the place in which they study), classmates or colleagues, having access to academic support namely faculty members to help them (Garcia \&Pintrich,1994).

Self-Regulation of Motivation and Affect: Learners can adjust themselves to the requirements of the training programs by modifying motivational beliefs particularly self-efficacy and goal orientation. In addition, students can learn to control their emotions and affect in ways that improve their learning. Self-efficacy concepts necessarily mean the learner's perception of ability to organize and perform activities to obtain an academic objective (Bandura, 1997).Self-efficacy also is related to students' assurance in their cognitive, emotional and learning competencies in doing an activity. Goal orientation is comprised of two aspects: mastery goal orientation and extrinsic orientation. A mastery goal orientation is best described as applying self-set guideline and self-improvement to learning and mastering the task. Extrinsic orientation is connected with the prevailing criterion to obtain resource investments; that is to say anticipated encouragement or avoiding punishment (Pintrich, 1999).

Self-Regulation of Cognition: requires the management of several cognitive strategies for learning, such as applying of profound processing strategies in order to better learning and performance than students showed previously.

Zimmerman (2000) suggested three recurring phases for self-regulation process with the inclusion of forethought, performance (volitional control) and self-reflection. Forethought phase or pre-action phase is the primary stage in which learners get closer to the task. These stages contain setting goals, choice of strategies and techniques evaluating selfefficacy, assessing mastery or goal orientation and discovering interest. In performance phase is dealt with the action. Learners' focus on the task is essential to improve their performance during concentrating (excluding distractions and other competing attentions), self-instruction and self-monitoring of progress. The last stage is self-reflection or postaction phase. It signifies the employment of guidelines to create self-judgments concerning the performance together with self-evaluation on a standard or goal, attributions to skill or attempt, self-reactions and adjustments.

Research reveals the fact that self-regulated learning to be appropriately associated with academic achievement. Empirical studies indicated a significant relationship between academic success and the use of regulatory skills and an understanding of how to use these skills (Cross \& Paris, 1988; Zimmerman \& Schunk, 2001). The use of adequate selfregulatory learning strategies is fundamental for students to have academic success in higher education (Sitzmann \& Ely, 2011). According to Zimmerman (1989), self-regulated learners can set goals actively, find well suited strategies, manage their time, arrange materials and information, observe their learning and look for feedback on their performance.EFL teachers' self-regulation has been found to be associated with effective teaching (MonshiToussi, Boori, \& Ghanizadeh, 2011), teacher self-efficacy (Ghonsooly \& Ghanizadeh, 2013), and critical thinking (Ghanizadeh, 2011). In another research, the relationship between self-efficacy and self-regulation in vocabulary acquisition with Iranian EFL learners was investigated. The result indicated that there is a significant relationship between self-efficacy and self-regulation in vocabulary acquisition among the participants (Haji Hassan Hamedani, 2013). Furthermore, it has also been found that self-regulation has acontributing role in enhancing EFL teachers' sense of self-efficacy (Ghonsooly \& Ghanizadeh, 2013).

Based on the theoretical contentions stated earlier, learners' metacognitive awareness and self-regulation are important characteristics to consider in understanding academic success. So delving into these constructs deserves specific attention. In this study, the mediating roles of translation studies students' gender and educational level in selfregulation and metacognitive awareness were examined.

\section{Research Questions}

The following research questions were posed and investigated in the present study: 
1. Is there any significant relationship between translation students' metacognitive awareness and their gender?

2. Is there any significant relationship between translation students' self-regulation and their gender?

3. Is there any significant relationship between translation students' metacognitive awareness and their educational level?

4. Is there any significant relationship between translation students' self-regulation and their educational level?

\section{Method}

\subsection{Participants}

The participants of this study were students in Translation Studies with two different levels B.A and M.A. The participants were selected from the students studying Translation Studies at Ferdowsi university of Mashhad, Imam Reza International University of Mashhad, and Quchan Azad University. A community sample of 230 students including 150 females and 80 males participated in this study. Due to participants' unwillingness or difficulty and time consuming procedure of participation, they did not fully cooperate in the research and the above number of participants decreased to 170. Out of 170 students, 105 were females and 65 males and also 100 were M.A and 70 were B.A (senior) students. Native language of participants was Persian. The average age of participants was 24; the youngest was 20 and the oldest was 38 years old $(\mathrm{M}=24.64, \mathrm{SD}=3.68)$. Participation in this study was on a voluntary basis.

\subsection{Instruments}

Two major instruments were utilized in this phase:

\subsubsection{Self-Regulation Trait (SRT) Questionnaire}

Students' self-regulated learning was measured by the self-regulation trait (SRT) questionnaire. The self-regulation trait (SRT) questionnaire was designed by O'Neil and Herl (1998). It was developed based on Zimmerman's self -regulation model. It consists of 32 Likert-scale questions ranging from almost never, to sometimes, often, and almost always. The scale seeks to measure metacognition and motivation dimensions. Each dimension comprises two sub-scales. Metacognition covers the constructs of planning and self-monitoring, and motivation contains effort and self-efficacy. The four scales are measured by 8 Likert-type items each. According to Herl et al (1999), the reliability and validity of the scale have been verified in multiple studies.

\subsubsection{Metacognitive Awareness Inventory (MAI)}

Schraw and Dennison (1994), who themselves built on Flavell's work to create their Metacognitive Awareness Inventory to measure students' metacognitive awareness. The MAI consists of 52 statements in a five point Likert scale type. The two components of metacognition discussed above are represented within the scale, metacognitive knowledge and metacognitive regulation. Within the MAI these are referred to as the knowledge of cognition factor and the regulation of cognition factor. Within the inventory there are 17 questions related to the knowledge of cognition factor for a possible point total of 85 . There are 35 questions related to the regulation of cognition factor for a possible point total of 175. The factor scores are calculated by adding the scores on questions related to each of the factors. Higher scores correspond to greater metacognitive knowledge and greater metacognitive regulation. In addition to the knowledge of cognition score and the regulation of cognition score a MAI total score is derived by summing responses to all 52 questions. The instrument was designed for use on adult populations. Operational definitions of component categories of this inventory are presented below:

\section{Knowledge of Cognition}

1. Declarative knowledge: knowledge about one's skills, intellectual resources, and abilities as a learner.

2. Procedural knowledge: knowledge about how to implement learning procedures (e.g., strategies).

3. Conditional knowledge: knowledge about when and why to use learning procedures.

\section{Regulation of Cognition}

1. Planning: planning, goal setting, and allocating resources prior to learning.

2. Information management: skills and strategy sequences used on-line to process information more efficiently (e.g., organizing, elaborating, summarizing, selective focusing).

3. Monitoring: assessment of one's learning or strategy use.

4. Debugging: strategies used to correct comprehension and performance errors.

5. Evaluation: analysis of performance and strategy effectiveness after a learning episode.

(Schraw\& Dennison, 1994, p. 474)

\subsection{Procedure}

Data collection process started in September 2014. After identifying the sample of participants, they were asked to complete the self-regulation questionnaire including 32 items. Simultaneously, they were given metacognitive awareness questionnaire. Then they were asked to complete the questionnaires in their spare time carefully and honestly. 


\section{Results}

The results of applying the methodology are presented and analyzed in order to extract meaningful data from the raw statistics. These findings are then discussed to clarify how they can contribute to the purpose of the study.

\subsection{Descriptive Statistics}

To investigate the normality of the distribution, descriptive statistics for the scale-level data of the Metacognitive Awareness inventory, Self-regulation Trait questionnaire and translation Ability were analyzed based on the 170 participants. Table 1 presents descriptive statistics of translation students' metacognitive awareness, self-regulation.

Table 1. Descriptive Statistics for the Scale-level Data of the Questionnaires

\begin{tabular}{|c|c|c|c|c|c|c|c|}
\hline Measured Variables & $\mathrm{N}$ & Minimum & Maximum & Mean & $\begin{array}{l}\text { Std. } \\
\text { Deviation }\end{array}$ & Skewness & Kurtosis \\
\hline Declarative knowledge & 170 & 17.00 & 39.00 & 29.1706 & 5.13951 & -.419 & -.468 \\
\hline Procedural knowledge & 170 & 6.00 & 20.00 & 14.0000 & 2.64910 & -.460 & .135 \\
\hline Conditional knowledge & 170 & 8.00 & 25.00 & 18.1235 & 3.53378 & -.420 & -.285 \\
\hline Planning & 170 & 12.00 & 34.00 & 24.7882 & 5.00555 & -.265 & -.551 \\
\hline $\begin{array}{l}\text { Information Management } \\
\text { Strategy }\end{array}$ & 170 & 19.00 & 47.00 & 35.4824 & 6.31072 & -.451 & -.392 \\
\hline Comprehension Monitoring & 170 & 14.00 & 34.00 & 24.7471 & 4.25526 & -.355 & .009 \\
\hline Debugging Strategy & 170 & 7.00 & 25.00 & 18.5471 & 3.64564 & -.609 & .131 \\
\hline Evaluation & 170 & 11.00 & 28.00 & 20.7647 & 3.89400 & -.502 & -.138 \\
\hline $\begin{array}{l}\text { Total Metacognitive } \\
\text { Awareness }\end{array}$ & 170 & 108.00 & 244.00 & 185.6235 & 29.37756 & -.471 & -.147 \\
\hline Planning & 170 & 14.00 & 31.00 & 21.7059 & 3.97574 & .066 & -.685 \\
\hline Self-monitoring & 170 & 14.00 & 30.00 & 22.4059 & 4.02286 & -.260 & -.880 \\
\hline Effort & 170 & 13.00 & 31.00 & 22.1765 & 4.08975 & .029 & -.676 \\
\hline Self-efficacy & 170 & 11.00 & 34.00 & 22.2824 & 4.07942 & .218 & -.044 \\
\hline Total Self-regulation & 170 & 58.00 & 123.00 & 88.5706 & 14.42008 & -.008 & -.687 \\
\hline
\end{tabular}

\subsection{Result of the Relationship between Variables and Gender}

To examine whether there is any significant difference between males and females regarding their metacognitive awareness, an independent samples t-test was run. Table 2 presents the results.

Table 2. The Results of Independent T-Test for Determining the Role of Gender in Metacognitive awareness and its components

\begin{tabular}{|c|c|c|c|c|c|}
\hline & $\mathrm{t}$ & $\mathrm{df}$ & $\begin{array}{l}\text { Sig. (2- } \\
\text { tailed) }\end{array}$ & $\begin{array}{l}\text { Mean } \\
\text { Difference }\end{array}$ & $\begin{array}{l}\text { Std. } \\
\text { Error } \\
\text { Difference }\end{array}$ \\
\hline $\mathrm{DEC}$ & .168 & 167 & .867 & .13654 & .81310 \\
\hline PRO & .251 & 167 & .802 & .10577 & .42057 \\
\hline $\mathrm{CON}$ & .532 & 167 & .596 & .29808 & .56049 \\
\hline PLN & .371 & 167 & .711 & .29231 & .78778 \\
\hline IMS & .419 & 167 & .676 & .41731 & .99643 \\
\hline MON & .364 & 167 & .716 & .24423 & .67069 \\
\hline DEB & .877 & 167 & .382 & .50577 & .57699 \\
\hline EVA & .383 & 167 & .702 & .23654 & .61783 \\
\hline TOTAL & .482 & 167 & .630 & 2.23654 & 4.63766 \\
\hline MA & & & & & \\
\hline
\end{tabular}

As Table 2 indicates, there were no significant differences between gender and the subscales of metacognitive awareness as follows: declarative knowledge $(t=.167, \mathrm{p}>0.05)$, procedural knowledge $(t=.255, \mathrm{p}>0.05)$, conditional knowledge $(t=.538, \mathrm{p}>0.05)$, planning $(t=.371, \mathrm{p}>0.05)$, information management strategy $(t=.430, \mathrm{p}>0.05)$, comprehension monitoring $(t=.362, \mathrm{p}>0.05)$, debugging strategy $(t=.924, \mathrm{p}>0.05)$, evaluation $(t=.387, \mathrm{p}>0.05)$ and total metacognitive awareness $(t=.495, \mathrm{p}>0.05)$. This can be figured out by examining the magnitude of $t$ which should be higher than that of critical $t$, and the amount of $p$-value which should be lower than 0.05 . 
Independent samples $t$-tests were run to investigate the role of gender in the level of participants' self-regulation. As indicated in Table 3, there is no impact of gender on self-regulation and any of its subscales. In other words, male and female do not differ in their level of self-regulation. The $t$-value for each factor is: planning $(t=.475, p>0.05)$, selfmonitoring $(t=.264, p>0.05)$, effort $(t=.178, p>0.05)$, self-efficacy $(t=.181, p>0.05)$, and total self-regulation $(t=$ $.308, p>0.05)$.

Table 3. The Results of Independent T-Test for Determining the Role of Gender in Self-regulation and its components

\begin{tabular}{|c|c|c|c|c|c|}
\hline & $\mathrm{t}$ & df & Sig. (2-tailed) & Mean Difference & $\begin{array}{l}\text { Std. Error } \\
\text { Difference }\end{array}$ \\
\hline Planning & .486 & 167 & .628 & .30577 & .62973 \\
\hline Self-monitoring & .270 & 167 & .788 & .17115 & .63459 \\
\hline Effort & .178 & 167 & .859 & .11538 & .64775 \\
\hline Self-efficacy & .176 & 167 & .861 & .11346 & .64622 \\
\hline $\begin{array}{l}\text { TOTAL } \\
\text { Self-regulation }\end{array}$ & .310 & 167 & .757 & .70577 & 2.27923 \\
\hline
\end{tabular}

\subsection{Result of the Relationship between Variables and Educational level}

To examine whether there is any significant difference between BA and MA students regarding their metacognitive awareness, an independent samples $t$-test was run. Table 4 presents the results.

Table 4. The Results of Independent T-Test for Determining the Role of Education level in Metacognitive Awareness and its Components

\begin{tabular}{lccccc}
\hline & & & & & \\
& $\mathrm{t}$ & $\mathrm{df}$ & Sig. (2-tailed) & Mean Difference & $\begin{array}{c}\text { Std. Error } \\
\text { Difference }\end{array}$ \\
\hline DEC & -2.206 & 168 & .029 & -1.74714 & .79192 \\
\hline PRO & -1.897 & 168 & .060 & -.77714 & .40970 \\
\hline CON & -2.631 & 168 & .009 & -1.42429 & .54130 \\
\hline PLN & -.783 & 168 & .435 & -.61143 & .78095 \\
\hline IMS & -1.809 & 168 & .072 & -1.76714 & .97691 \\
\hline MON & & & & & \\
\hline DEB & -1.893 & 168 & .060 & -1.24571 & .65812 \\
\hline EVA & -.567 & 168 & .571 & -.32286 & .56928 \\
\hline MOTAL & -2.374 & 168 & .019 & -1.42143 & .59868 \\
\hline
\end{tabular}

As indicated in Table 4, there is a negative significant impact of educational level on total metacognitive awareness $(t=$ $-2.065, p>0.05$ ), and some components of metacognitive awareness. In other words, MA students were shown to have higher levels of metacognitive awareness in comparison with their BA counterparts. There are significant impacts on: 
declarative knowledge $(t=-2.203, p>0.05)$, conditional knowledge $(t=-2.611, p>0.05)$ and evaluation $(t=-2.409$, $p>0.05)$.

Table 5. The Results of Independent T-Test for Determining the Role of Educational level in Self-regulation and its Subscales

\begin{tabular}{lccccc}
\hline & $\mathrm{t}$ & $\mathrm{df}$ & Sig. (2-tailed) & Mean Difference & $\begin{array}{c}\text { Std. Error } \\
\text { Difference }\end{array}$ \\
\hline Planning & -.839 & 168 & .403 & -.52000 & .62012 \\
\hline Self-monitoring & -.945 & 168 & .346 & -.59286 & .62711 \\
\hline Effort & -.584 & 168 & .560 & -.37286 & .63859 \\
\hline $\begin{array}{l}\text { Self-efficacy } \\
\text { TOTAL Self- }\end{array}$ & -.831 & 168 & .407 & -.52857 & .63632 \\
\begin{tabular}{l} 
regulation \\
\hline
\end{tabular} & -.896 & 168 & .372 & -2.01429 & 2.24852 \\
\hline
\end{tabular}

As Table 5shows, there were no significant differences between educational level and self-regulation and its subscales .In other words, M.A and B.A do not differ in their level of self-regulation as follow: planning $(t=-.845, p>0.05)$, selfmonitoring $(t=-.936, p>0.05)$, effort $(t=-.589, p>0.05)$, self-efficacy $(t=-.863, p>0.05)$, and total self-regulation $(t=$ $.905, p>0.05)$.

\section{Discussion \&Conclusion}

The present research sought to probe the role of gender and educational level in translation students' metacognitive awareness and self-regulation.

No significant relationship was found between the degree of translation students' metacognitive awareness and gender. The findings indicated that generally both males and females use their metacognitive skills in translation. That is, the metacognitive awareness strategies were not dependent on gender .Some researchers suggested that there are differences regarding males' and females' metacognitive skills (Logan \& Johnston, 2009; Ozkan \& Hatice, 2013), while others suggest that these differences are not significant (e.g. Berkant's, 2009; Benson, 2001; Vianty, 2007). A study by Rahman, etal. (2010) supported the findings of the present study indicating that there was no significant difference between metacognition of male and female science students. Also, the result is collateral with the finding of research study by Zulkiply (2006), who found that there is no significant difference in metacognition awareness between male and female across all academic years. On the other hand, the finding of this study is in contrary with Miller (2000) who found out that girls have more metacognitive skills in Mathematics compared to boys.

The results also indicated that there was no significant difference between male and female students in using selfregulated strategies. Thus, it can be contended that the students who participated in this study had developed the skills of being proactive in self-management and to taking initiative in making decisions (Zeidner, Boekaerts \& Pintrich 2000) irrespective of gender. Not much is known about any previous literature that showed clear evidence on gender difference in self-regulation. Perhaps more studies are needed to be done on this issue.

The result revealed that there was a negative significant relationship between metacognitive awareness and educational level. Also some components of metacognitive awareness (declarative knowledge, conditional knowledge and evaluation) showed negative significant relationship. It indicated that M.A translation students have more knowledge about their skills, how to implement learning procedures, and analysis of performance. In other words, MA students were shown to have higher levels of metacognitive awareness in comparison with their BA counterparts. This would appear to suggest that students' metacognition in relation to their grade level tends to increase over time and with every year of educating. Data demonstrated that a higher education level corresponds to a higher metacognitive awareness. In other words, the more a translation student is educated and experienced, the more s/he tends to have knowledge about cognition and regulation of cognition. The results also provided a mean of support to previous research on the relationship of metacognitive awareness and academic achievement. The results of the study indicated that metacognition might play an important role in academic achievement of the translation students.

Building upon the results of the current study, there was not any difference in scores on self-regulation between M.A and B.A translation students. There was not a significant difference between these two groups. Given that, to the researcher's best knowledge, there is no documented study exploring the role of educational level in translation students' perceived self-regulation, no cross comparison can be made with reference to previous translation related research. We can convincingly conclude that the issue of educational level differences in self-regulation does not appear to generalize to translation and both B.A and M.A translation students deploy somewhat similar self-regulation strategies. 
Improvements in translation, assessment of metacognitive awareness and self-regulation, and consistent and explicit training of students may increase students' metacognition regardless of gender and educational level. Further research is needed in the area of translation students' metacognitive awareness and self-regulation. Applying multiple indicators of metacognition and self-regulation, such as self-report inventories and reflection-in-action methods would lead to more validity of the results. M.A translation educators require an understanding of the definition and strategies of metacognition. More studies should investigate the transfer of metacognitive skills to practical settings and the instructional strategies to improve metacognition of translation students in higher education.

It is also suggested that future research replicate thisstudy using a larger number of translation students and compare different ages or ethnic groups. Although this research studied about gender, there were imbalances in the number of male and female participants. The researcher recommends that future research put more effort in balancing the proportion of males and females.

\section{References}

Al-Harthy, I., Was, C., \& Isaacson, R. (2010). Goals, efficacy and metacognitive self-regulation: a path analysis. International Journal of Education, 2, 1-20.http://dx.doi.org/10.5296/ije.v2i1.357

Bandura, A. (1977). Self-efficacy: Toward a unifying theory of behavioral change. Psychological Review, 84, 191215.http://dx.doi.org/10.1037/0033-295X.84.2.191

Berkant, H. G. (2009). An investigation of students' meaningful causal abilities in terms of academic achievement, reading comprehension and gender. Educational Sciences: Theory \& Practice, 9(3), 1149-1165.

Bransford, J. D., A. L. Brown, and Cocking, R.R., eds. (2000). How People Learn. Washington, D.C., National Academy Press

Bronson, M. B. (2000). Self-regulation in early childhood: Nature and nurture. New York: Guilford Press.

Chesterman, A. (2009). The name and nature of translator studies. Hermes, Journal of Language and Communication Studies, 42 , 13-22.

Coffey, H. (2009).The relationship between metacognition and writing in sixth grade mathematics.Tesis Doctor of Education Teacher Leadership, Education, Walden University.

Coutinho, S. A. (2007). The relationship between goals, metacognition, and academic success. Educate, 7(1), 39-47.

Cross, D. R., and Paris, S. G. (1988).Developmental and instructional analyses of children's metacognition and reading comprehension. J. Educ. Psychol. 80: 131-142.http://dx.doi.org/10.1037/0022-0663.80.2.131

Dam, Helle V., and Karen KorningZethsen (2008).“Translator Status.A Study of Danish Company Translators.'In The Translator 14(1), 71-96.http://dx.doi.org/10.1080/13556509.2008.10799250

Diriker, Ebru (2004) De-/Re-Contextualizing Conference Interpreting: Interpreters in the Ivory Tower? Amsterdam and New York: John Benjamins.http://dx.doi.org/10.1075/btl.53

Flavell, J. (1979). Metacognition and cognitive monitoring: a new area of cognitive developmental inquiry. American Psychologist, 34 (10), 906-11.http://dx.doi.org/10.1037/0003-066X.34.10.906

Garcia, T., \&Pintrich, P. R. (1994).Regulating motivation and cognition in the classroom: The role of self-schemas and selfregulatory strategies. In D. H. Schunk, \& B. J. Zimmerman, Self-regulation of learning and performance: Issues and educational applications (pp. 127\}153). Hillsdale, NJ: Lawrence Erlbaum Associates.

Garner, R., and Alexander, P. A. (1989). Metacognition: Answered and unanswered questions. Educ. Psychol. 24: 143158.http://dx.doi.org/10.1207/s15326985ep2402_2

Ghanizadeh, A. (2011.). An investigation of the Iranian EFL teachers' self-regulation and critical thinking.The Journal of Technology \& Education, 5(3), 213-221.

Ghonsooly, B., \&Ghanizadeh, A. (2013). Self-efficacy and self-regulation and their relationship: a study of Iranian EFL teachers, The Language Learning Journal, 41 (1), 68-84. http://dx.doi.org/10.1080/09571736.2011.625096

Haji Hassan Hamedani, S. (2013). The Relationship between Self-Efficacy and Self- Regulation in Vocabulary Acquisition of Iranian EFL Learners. Journal of Academic and Applied Studies,3(1),20-31.

Heidari, F. \&Bahrami, Z. (2012).The relationship between thinking styles and metacognitive awareness among Iranian EFL learners. International Journal of Linguistics, 4 (3), 721-733.http://dx.doi.org/10.5296/ijl.v4i3.2061

Herl, H. E., O’Neil, H. F., Jr., Chung, G. K. W. K., \&Schacter, J. (1999).Reliability and validity of a computer-based knowledge mapping system to measure content understanding. Computer in Human Behavior, 15, 315333.http://dx.doi.org/10.1016/S0747-5632(99)00026-6

Kassaian, Z., \&Ghadiri, M. (2011). An investigation of the relationship between motivation, and metacognitive awareness strategies in listening comprehension: The case of Iranian EFL learners. Journal of Language Teaching and Research, 2(5), 10691079. http://dx.doi.org/10.4304/jltr.2.5.1069-1079

Koskinen, K. (2008). Translating Institutions.An Ethnographic Study of EU Translation. Manchester: St. Jerome Publishing.

Kruger, J., \& Dunning, D. (1999). Unskilled and unaware of it: How difficulties in recognizing one's own incompetence lead to inflated self-assessment. Journal of Personality and Social psychology, 77, 1121-1134.http://dx.doi.org/10.1037/0022- 
3514.77.6.1121

Logan, S. \& Johnston, R.S. (2010).Investigating gender differences in reading. Educational Review, 62(2), 175187.http://dx.doi.org/10.1080/00131911003637006

Miller, J.W. (2000). "Exploring the Source of Self-regulated Learning: The Influence of Internal and External Comparisons. Journal of Instructional Pyschology . 27: 47-52.

MohammadiGhavam, M., Rastegar, M., \&Razmi, M. H. (2011).Iranian EFL learners' achievement goals in relation with their metacognitive reading strategy use. Open Journal of Modern Linguistics, 1(2), 39-44. http://dx.doi.org/10.4236/ojml.2011.12006

MonshiToussi, M. T., Boori. A.,\&Ghanizadeh. A. (2011).The role of EFL teachers' self-regulation in effective teaching.World Journal of Education, 1(2), pp. 39-48. http://dx.doi.org/10.5430/wje.v1n2p39

Negretti, R., \&Kuteeva, M. (2011). Fostering metacognitive genre awareness in L2 academic reading and writing: A case study of pre-service English teachers. Journal of Second Language Writing, 20, 95-110. http://dx.doi.org/10.1016/j.jslw.2011.02.002

O’Neil, H. F., Jr., \&Herl, H. E. (1998, April). Reliability and validity of a trait measure of self-regulation. Paper presented at the annual meeting of the American Educational Research Association, San Diego, CA.

Ozkan, C., \&Hatice, O. (2013).Investigating science high school students' metacognitive awareness and self-efficacy perceptions with some respect to the some individual and academic variables. International Journal of Human Science, 10(2), $246-259$.

Pintrich, P. R. (1995). Understanding self-regulated learning. New Directions for Teaching and Learning, 63, pp.312.http://dx.doi.org/10.1002/tl.37219956304

Pintrich, P. R., \&Schunk, D. H. (2002).Motivation in education: Theory, research, and applications $\left(2^{\text {nd }}\right)$. Upper Saddle River, NJ: Merrill/Prentice Hall.

Pressley, M., \&Ghatala, E. S. (1990). Self-regulated learning: Monitoring learning from text. Educ. Psychol. 25, 1933.http://dx.doi.org/10.1207/s15326985ep2501_3

Rahman, F., Jumani, N., Chaudry, M.A., CHisti. S., \&Abbasi, F.(2010). “Impact Of Metacognitive Awareness On Performance Of Students In Chemistry". Contemporary Issues In Education Research.

Robinson, D. (1997). Becoming a translator: An accelerated course. London and New York: Routledge.

Schraw, G. (1994). The effect of metacognitive knowledge on local and global monitoring.Contemporary Educational Psychology, 19, 143-154.http://dx.doi.org/10.1006/ceps.1994.1013

Schraw, G. (1998). Promoting general metacognitive awareness.Instructional Science, 26, 113125.http://dx.doi.org/10.1023/A:1003044231033

Schraw, G., \& Dennison, R. S. (1994).Assessing metacognitive awareness.Contemporary Educational Psychology, 19, 460475.http://dx.doi.org/10.1006/ceps.1994.1033

Schraw, G., \&Moshman, D. (1995) Metacognitive Theories.Educational Psychology Review, 7 (4), 351-371.

Schunk, D. H. (2005). Self-regulated learning: The educational legacy of Paul R. Pintrich. Educational Psychologist, 40, 85-94.

Sheory, R., \&Mokhtari, K. (2001).Differences in the metacognitive awareness of Reading strategies among native and non-native readers.System, 29, 431- 449.http://dx.doi.org/10.1016/S0346-251X(01)00039-2

Sitzmann, T., \& Ely, K. (2011). A meta-analysis of self-regulated learning in work-related training and educational attainment: What we know and where we need to go. Psychological Bulletin, 137, 421-442.http://dx.doi.org/10.1037/a0022777

Vandergrift, L. (2005). Relationships among motivation, orientations, metacognitive awareness, and proficiency in L2 listening. Applied Linguistics, 26(1), 70-89.http://dx.doi.org/10.1016/j.lindif.2008.10.005

Vianty M.( 2007) The comparison of students' use of metacognitive reading strategies between reading in Bahasa Indonesia and in English. IntEducJ.;8(2):449-460

Wolf, M. \& A. Fukari (2007). Constructing a Sociology of Translation. Amsterdam: John Benjamins. pp. 109119.http://dx.doi.org/10.1075/btl.74

Young, A., \& Fry, J. D. (2008).Metacognitive awareness and academic achievement in college students.Journal of the Scholarship of Teaching and Learning, 8(2), 1-10.

Zeidner, M., Boekaerts, M., \&Pintrich, P.R. (2000). Self-regulation: Directions and challenges for future research. In M. Boekaerts, P.R .Pintrich, \& M. Zeidner (Eds.), handbook of self-regulation (pp. 749-768). San Diego: Academic Press.http://dx.doi.org/10.1016/B978-012109890-2/50052-4

Zhang, L. J., \& Wu, A. (2009). Chinese senior high school EFL students metacognitive awareness and reading-strategy use. Reading in a Foreign Language, 21(1), 37-59.

Zimmerman, B. J. (2000). Attaining self-regulation: A social cognitive perspective. In M. Boekaerts, P.R. Pintrich, \& M. Zeidner (Eds.), Handbook of self-regulation (pp. 13-39). San Diego, CA: Academic Press. http://dx.doi.org/10.1016/B978012109890-2/50031-7

Zimmerman, B. J. (2002). Becoming a self-regulated learner: An overview.Theory into practice, 41, 6472.http://dx.doi.org/10.1207/s15430421tip4102_2 
Zimmerman, B. J., \&Schunk, D. (1989). Self-regulated learning and academic achievement: Theory, research, and practice. New York: Springer. http://dx.doi.org/10.1007/978-1-4612-3618-4

Zimmerman, B. J., \&Schunk, D. (2001).Reflections on theories of self-regulated learning and academic achievement.In B. Zimmerman and D. Schunk (Eds.), Self-Regulated Learning and Academic Achievement: Theoretical Perspectives (2nd Ed.) (pp. 289-307). Mahwah, NJ: Erlbaum.

Zulkiply, N., Kabit, M.R., \&Ghani, K.A. (2008). Metacognition: What roles does it play in students' academic performance?. The International Journal of Learning, 15, 97-105 